\title{
PSYCHOPHYSIOLOGICAL STATUS IN OVERWEIGHT INDIVIDUALS
}

\author{
T.V. Popova ${ }^{1}$, tati.popova2010@yandex.ru, ORCID: 0000-0002-5060-8132, \\ B. Pance ${ }^{2}$, lepansebénédicte@yahoo.fr, \\ G.I. Maksutova1, sandugac2011@yandex.ru, ORCID: 0000-0002-5518-9459, \\ Yu.B. Korableva1, julya-74@yandex.ru, ORCID: 0000-0003-2337-3531, \\ O.G. Kourova', olga.k5691@mail.ru, ORCID: 0000-0002-8544-7631 \\ ${ }^{1}$ South Ural State University, Chelyabinsk, Russian Federation, \\ ${ }^{2}$ Le Panse Academy, Paris, France
}

\begin{abstract}
Aim. The article deals with establishing psychophysiological features in overweight women to develop a set of measures for weight decrease and psychocorrection. Materials and methods. We studied two groups of women who were willing to participate in the study: the first group mean age $54.2 \pm 3.0$; the second group - mean age $25.0 \pm 1.7$. The average BMI of the first group corresponded with obesity values $(32.3 \pm 1.6)$, while an average BMI of the second group was within the upper limit of reference values $(23.7 \pm 0.9)$. However, according to body composition data, there was a risk of BMI increase. As far as the percentage of adipose tissue exceeded the recommended values, recommended weight loss was $18.2 \pm 2.6 \mathrm{~kg}$ for the older group and $5.6 \pm 1.4 \mathrm{~kg}$ for the young group. Two groups of women of the same age with normal weight were examined as control groups. Results of the study revealed both age-related and psychophysiological features in women of different weight. EEG analysis showed that alpha rhythm amplitude in women from the first group was higher on average and frequency was lower compared to the second group. In the experimental group, we also revealed a higher level of delta activity in the frontal region at rest. The study of a psychoemotional status revealed that all participants hardly coped with stress. However, young participants overcame stress more easily compared to the older group. Anxiety assessment showed increased values of anxiety. In all participants, personal anxiety was almost at the same level within 48 points. Situational anxiety was higher in young women $(51.2 \pm 1.3$ and $49.6 \pm 2.1$ points, respectively). Conclusion. The most psychophysiological indicators identified functional stress, particularly in overweight older women. To preserve the optimal psychophysiological status of persons participating in weight correction programs, it is also necessary to correct a psychophysical status in accordance with age-related features.
\end{abstract}

Keywords: overweight, age, structure of body tissues, electroencephalography, psychoemotional state, functional stress.

Introduction. According to WHO statistics, more than a billion people are overweight [10]. In Russia, more than $30 \%$ of working age persons are obese, and $25 \%$ are overweight. WHO estimates obesity as a global epidemic which threatens millions of people. There is an established link between obesity and such diseases as type II diabetes mellitus, arterial hypertension, atherosclerosis, some malignant tumors, and musculoskeletal system diseases.

Preserving a standard body structure and optimal functional status requires to correct nutrition and practice physical exercises. Even 7-minute aerobic load each day for six weeks results in reducing fat mass and waist circumference as well as improving the cardiovascular system in young people [4].

The control of a balanced nutrition and body structure plays an important role in sport. A cor- relation between body composition and tolerance to intensive mental loads accompanied by adequate nutrition was studied in elite water polo athletes [5]. The conclusion was made that monitoring of body cell mass provides valuable information for assessing training effect and preventing performance reduction.

Quick fat loss results in the negative changes in a psycho-functional status. In 18 hours after weight cutting in elite wrestlers, the authors [6] revealed a change in the effectiveness of linear and angular kinematics of single-leg technique.

The results of the study on the mental aspects of eating behavior disorders were published $[1,3,15]$. It was established [11] that the psychological risk factors for excess weight in women are a low level of subjective control over important events and interpersonal relations, alexithymia tendencies, and an increased level of hetero- and 
autoagression. However, the issue of personality features and their connection with eating behavior in people with excess weight from different age groups is not sufficiently studied. The understanding of psychophysiological features in persons with excess weight is essential for developing the means of psychological obesity treatment.

Aim. This study aimed to reveal psychophysiological features in women with excess weight for further development of the program including means for weight loss and psychological correction.

Materials and Methods. We studied two groups of women of different age: the first group mean age $54.2 \pm 3.0$; the second group - mean age $25.0 \pm 1.7$. The average BMI of the first group corresponded with obesity values $(32.3 \pm 1.6)$, while an average BMI of the second group was within the upper limit of reference values (23.7 \pm $\pm 0.9)$. However, according to body composition data, there was a risk of BMI increase. All participants wanted to take part in a previously described weight correction program which includes the recommendations on nutritional rebalancing developed by B. Pance and psychological support training developed by T.V. Popova.

Control groups involved people of the same age with a standard weight who practiced activity on an occasional basis. Each group consisted of 15 persons. All participants were of the same professional field (university professors and employees, school teachers and employees, students in natural sciences) and had no healthrelated complaints at the time of examination. All participants provided their informed consent in a written form.

Our examination included body composition and psycho-physiological functions analysis. composition parameters, bioelectrical impedance was measured with Tanita BC-418MA analyzer (certificate No 2005/806 dd. 06.06.2005) to analyze body composition parameters. The analysis of a psycho-emotional status was performed by using Spielberger State-Trait Anxiety Inventory [13], the self-assessment of well-being, activity, and mood proposed by V.A. Doskin [2], as well as psychological tests for the ability to overcome stress [7]. Electroencephalography (EEG) was conducted with Neuron-Spectrum equipment (Neurosoft, Russia) by using a standard scheme of multi-channel registration with 8 cup electrodes connected to ear electrodes and placed in accordance with the 10-20 system. We also registered the cardiointervalogram (CIG) by using a computer program for the analysis of heart rate (HR) structure and the spectrum of cardiac intervals; arterial pressure was measured according to the Korotkov's method.

The statistical processing of the data obtained was conducted with the help of the Statistica 6.0 software package (StatSoft, the USA) and SPSS. We calculated the arithmetic mean of variational series $(\mathrm{M})$, the mean error of arithmetic mean (m), and Student's t-criterion. A critical level of significance for statistical hypotheses was fixed at 0.05 .

Results. The results of the study revealed certain peculiarities of psychophysiological functions in persons with excess weight.

The group of older women (1) differed from the group of young women (2) by significantly higher body mass, fat mass, total water, and BMI. To achieve optimal performance, weight to lose for older women was 3 times higher than for young women (Table 1).

In older women, BMI values corresponded to obesity, while in the group of young women BMI values were within reference limits except for some participants whose BMI was $1-3 \mathrm{c}$. u. higher.

In control groups, all weight indicators were lower than in experimental groups. However, in the group of young women, differences were significant in terms of body weight, while in older women only the $4^{\text {th }}$ and $5^{\text {th }}$ groups of parameters were not statistically significant. The most pronounced differences were registered in body weight, fat mass in \%, and body weight to lose in $\mathrm{kg}$.

Despite the low weight index in participants from the control group, the majority of women show the necessity of losing weight to achieve optimal values. This means that the body weight index alone does not prove that body weight is normal. A comprehensive analysis of fat-free and fat tissue structure in different parts of the body is necessary for obesity prevention.

The distribution of fat-free and fat mass in the limbs and body is of particular interest (Fig. 1).

In both groups, we established a lower fat mass percentage in the body compared to the limbs and a greater fat mass in $\mathrm{kg}$. With a more significant amount of adipose tissue in older women, fat-free mass and muscle mass in all participants were greater than fat mass. In young women, fat mass in the body was significantly lower than in older women $(9.8 \pm 3.3$ and $18.8 \pm$ $\pm 4.1 \mathrm{~kg} ; \mathrm{P}<0.05)$. 
Indicators of body weight structure in participants

\begin{tabular}{|l|c|c|c|c|c|c|}
\hline \multirow{2}{*}{ Group } & \multicolumn{7}{|c|}{ Parameters } \\
\cline { 2 - 7 } & Weight, kg & BMI, c. u. & FAT, \% & TBW, kg & NFAT, \% & LOSE, kg \\
\hline 1 & $88.9 \pm 5.7$ & $32.3 \pm 1.6$ & $42.4 \pm 1.8$ & $36.9 \pm 1.6$ & $28.7 \pm 0.3$ & $18.2 \pm 2.6$ \\
\hline 2 & $64.1 \pm 2.5$ & $23.1 \pm 0.9$ & $30.4 \pm 1.6$ & $32.3 \pm 0.9$ & $26.9 \pm 0.3$ & $5.6 \pm 1.4$ \\
\hline $1 \mathrm{C}$ & $64.5 \pm 3.2$ & $22.9 \pm 0.9$ & $25.4 \pm 2.5$ & $33.2 \pm 0.8$ & $28 \pm 0.4$ & $5.1 \pm 1.5$ \\
\hline 2C & $57 \pm 2.8$ & $18.9 \pm 1.3$ & $23.6 \pm 2.6$ & $31.6 \pm 0.7$ & $25.8 \pm 1.5$ & $3.8 \pm 0.9$ \\
\hline P 1-1C & $<0.05$ & $<0.05$ & $<0.05$ & $<0.05$ & $>0.5$ & $<0.05$ \\
\hline P 2-2C & $<0.05$ & $<0.05$ & $<0.05$ & $>0.5$ & $>0.5$ & $<0.05$ \\
\hline
\end{tabular}

Note: 1, 2 - experimental groups, 1C, 2C - control groups. Weight - body weight, kg; BMI - body mass index, $\mathrm{kg} / \mathrm{cm}^{2} ; \mathrm{FAT} \%$ - fat mass, \%; TBW - total body water, $\mathrm{kg}$; NFAT - recommended fat mass, \%; LOSE - recommended weight to lose.

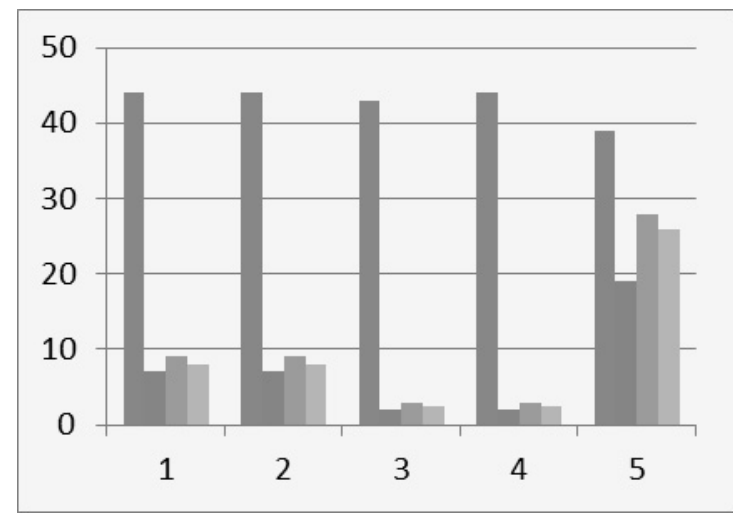

A

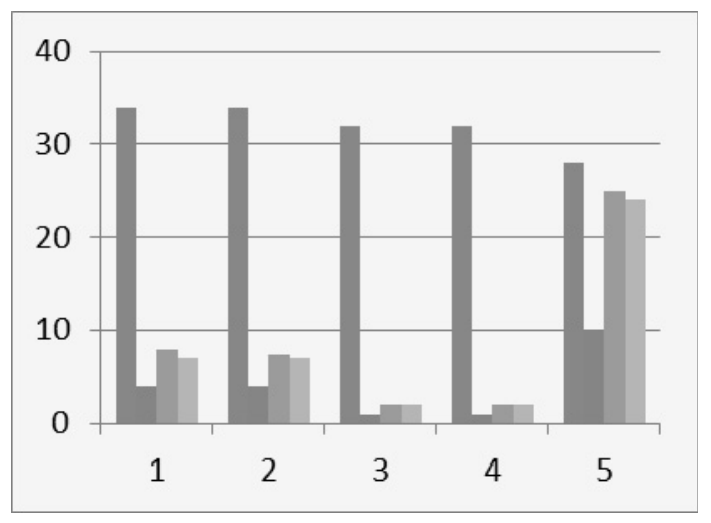

B

Fig.1. Body structure in older (A) and younger (B) women: 1, 2 - right and left arms; 3,4 - right and left legs; 5 - trunk. 1st bar in the group - fat tissue in \%, 2nd - in $\mathrm{kg}$; 3rd - fat-free tissue in $\mathrm{kg}$; 4th - muscle tissue in $\mathrm{kg}$

The study of a psychoemotional status revealed that all participants hardly coped with stress. However, young women overcame stress better $(53.2 \pm 2.2$ points $)$ compared to older women $(72.3 \pm 2.5$ points, $\mathrm{P}<0.05)$.

The assessment of anxiety level showed its increased values. In all participants, situational anxiety was almost the same within 48 points. Situational anxiety in young women was higher compared to older women (51.2 \pm 1.3 and $49.6 \pm$ \pm 2.1 points, respectively). This is possibly due to greater professional experience of participants from the older group.

The self-assessment test of a psychoemotional status did not reveal any significant differences between groups. Mood and well-being indicators were within 5.4-5.7 points, while activity indicators were lower (4.6-4.9 points).

Heart rate variability analysis revealed that HR in women from the first group was significantly higher compared to the second group $(81.8 \pm 4.5$ and $64.4 \pm 3.2 \mathrm{bpm} ; \mathrm{P}<0.05)$. The activity indicators of the sympathetic system
(AMo) in the first group were also higher $(50.7 \pm$ \pm 3.2 and $27.5 \pm 2.3 \%, \mathrm{P}<0.05$, respectively) as well as the activity indicators of central regulatory mechanisms (SI $120.8 \pm 5.6$ and $49.1 \pm 2.8$ cu., $\mathrm{P}<0.05)$. In participants from the first group, the indicators of vagosympathetic interaction (LF/HF) obtained in HR spectral analysis were 2 times higher compared to the second group. These data prove that functional stress in older women is more pronounced than in young women.

In the first group, average systolic arterial pressure was $132.6 \pm 4.6 \mathrm{mmHg}$; in the second group $-109.2 \pm 3.2 \mathrm{mmHg}(\mathrm{P}<0.05)$; diastolic pressure $-85.8 \pm 3.1$ and $73.0 \pm 2.2 \mathrm{mmHg}$, respectively $(\mathrm{P}<0.05)$. Therefore, in the first group, we revealed a tendency to hypertonia. In two women from the first group, arterial pressure indicators did not exceed 140/90 $\mathrm{mmHg}$.

EEG analysis showed (Table 2) that alpha rhythm amplitude in women from the first group was higher on average and frequency was lower compared to the second group. Frontal lobe dominance was more frequent, while occipital 
Comparative analysis of the bioelectrical activity of the brain in persons with different body weight indicators

\begin{tabular}{|c|c|c|c|c|c|c|c|}
\hline \multicolumn{2}{|c|}{ Groups } & $\begin{array}{c}\text { Alpha rhythm } \\
\text { amplitude, } \\
\text { mkV }\end{array}$ & $\begin{array}{c}\text { Alpha rhythm } \\
\text { frequency, Hz }\end{array}$ & $\begin{array}{c}\text { Low-frequency } \\
\text { beta rhythm } \\
\text { index, } \%\end{array}$ & $\begin{array}{c}\text { High-frequency } \\
\text { beta rhythm } \\
\text { index, } \%\end{array}$ & $\begin{array}{c}\text { Alpha rhythm } \\
\text { dominance } \\
\text { in the right region }\end{array}$ & $\begin{array}{c}\text { Alpha rhythm } \\
\text { dominance } \\
\text { in the left region }\end{array}$ \\
\hline \multirow{2}{*}{1} & B & $12 \pm 4.8$ & $8.9 \pm 1.5$ & $4 \pm 1.8$ & $7 \pm 2.6$ & $\begin{array}{c}\text { Frontal, parietal, } \\
\text { occipital }\end{array}$ & Parietal, frontal \\
\cline { 2 - 8 } & $\mathrm{R}$ & $77.4 \pm 3.8$ & $9.65 \pm 0.8$ & $5 \pm 2.1$ & $8 \pm 1.5$ & Occipital & $\begin{array}{c}\text { Central, } \\
\text { occipital }\end{array}$ \\
\hline 1C & $\mathrm{B}$ & $9.5 \pm 3.1$ & $9.6 \pm 1.3$ & $4 \pm 0.9$ & $7.8 \pm 3.3$ & Frontal, occipital & Parietal \\
\hline & $\mathrm{R}$ & $135.5 \pm 7.5^{*}$ & $10.6 \pm 1.4$ & $5 \pm 2.2$ & $9 \pm 2.6$ & Occipital & Occipital \\
\hline \multirow{2}{*}{2} & $\mathrm{~B}$ & $11 \pm 2.2$ & $9.5 \pm 1.8$ & $3 \pm 0.7$ & $7.3 \pm 3.2$ & Frontal, occipital & $\begin{array}{c}\text { Temporal, } \\
\text { occipital }\end{array}$ \\
\hline & $\mathrm{R}$ & $66.4 \pm 4.7^{* *}$ & $10.2 \pm 1.1$ & $4 \pm 2.1$ & $5 \pm 2.2^{* *}$ & Occipital & Central, parietal \\
\hline \multirow{2}{*}{ 2C } & $\mathrm{B}$ & $13 \pm 2.6$ & $8.9 \pm 0.9$ & $3 \pm 1.2$ & $6.5 \pm 2.5$ & $\begin{array}{c}\text { Frontal, parietal, } \\
\text { occipital }\end{array}$ & $\begin{array}{c}\text { Frontal, } \\
\text { temporal, } \\
\text { occipital }\end{array}$ \\
\hline & $\mathrm{R}$ & $184 \pm 6.8^{*}$ & $10.5 \pm 1.6$ & $4 \pm 1.4$ & $6 \pm 2.4$ & Occipital & Occipital \\
\hline
\end{tabular}

Note: 1 - older group; 2 - young group; $1 \mathrm{C} / 2 \mathrm{C}$ - control groups. $\mathrm{B}$ - background conditions, $\mathrm{R}$ - relaxation; * - significant differences between experimental and control groups; ** - significant differences between the first and the second groups.

lobe dominance was found only in one person. During relaxation, alpha rhythm appeared mainly in occipital lobes. However, its amplitude was significantly lower compared to control groups.

Compared to control groups, in the majority of overweight women $(80 \%)$, we registered deltafrequency slow-waves (frontal, central, temporal regions), and in $10 \%$ of women, we also found theta-frequency waves in the frontal region.

Therefore, in the majority of groups, we revealed the EEG signs of functional stress.

Discussion. The results of our study prove the increase of psychoemotional and functional stress in overweight persons. European scientists also admit that constant stress among both professors and university students contributes to psychoemotoional and functional stress [8]. More intensive physical loads can explain the fact that this stress is more pronounced in the older group than in the young group. Moreover, with the increase of physical activity in young women, there is a decrease in adipose tissue in the body [17]. This is possibly connected with a decrease in the so-called obesity factors contributing to the development of metabolic syndrome [9].

Neurohormonal mechanisms play an important role in weight regulation. For example, the study of Clozapine antipsychotic medication [12] revealed that in the majority of participants Clozapine caused weight increase against the improvement of mental status. However, certain participants demonstrated a weight decrease.
It was established [14] that neurotransmitters and neuropeptides contribute to the inclination to obesity through a complex chain of reactions.

The histamine inhibition of the mesolimbic pathway involved in appetite regulation was studied. It was established that the agonists of $\mathrm{H} 1$ receptors decrease appetite and food intake. Leptin is one more anorexigenic hormone which acts through histamine. Some other neuropeptides such as an $\alpha$-melanocyte-stimulating hormone, leptin, insulin, and glucagon are considered as playing a role in appetite decrease [16]. Therefore, psychophysical correction of the body contributes to a psychological status and normalizes body weight through neurohormonal mechanisms.

Conclusion. Our previous studies showed that psychophysical relaxational self-regulation contributes to the optimization of a psychophysical status against weight cutting in wrestlers [8]. This study proves the increase of psychoemotional and functional stress in untrained overweight women. These facts allow us to recommend psychophysical correction for optimizing psychophysical status during weight decrease in women of the age groups studied.

\section{References}

1. Corstorphine E., Waller G., Lawson R., Ganis C. Trauma and Multi-Impulsivity in the Eating Disorders. Eating Behaviors, 2007, no. 8, pp. 23-30. DOI: 10.1016 /j.eatbeh 2004. 08.009

2. Doskin V.A., Grombakh S.M. [Prevention 


\section{Физиология}

of Exam Stress]. Shkola $i$ psikhicheskoye zdorov'ye uchashchikhsya [School and Mental Health of students], 1988, pp. 147-160. (in Russ.)

3. Fabricatore A.N., Wadden T.A. Psychological Aspects of Obesity. Clinics in Dermatology, 2004, vol. 22 (4), pp. 332-337. DOI: 10.1016/j.clindermatol.2004.01.006

4. Mattar L., Farran N., Bakhour D. Effect of 7-Minute Workout on Weight and Body Composition. The Journal of Sports Medicine and Physical Fitness, 2017, vol. 57 (10), pp. 1299-1304. DOI: $10.23736 / \mathrm{S} 0022-4707.16 .06788-8$

5. Melchiorri G., Viero V., Sorge R., Triossi T., Campagna A., Volpe S.L., Lecis D., Tancredi V., Andreoli A. Body Composition Analysis to Study Long-Term Training Effects in Elite Male Water Polo Athletes. The Journal of Sports Medicine and Physical Fitness, 2018, vol. 58(9), pp. 1269-1274. DOI: $10.23736 / \mathrm{S} 00224707.17 .07208-5$

6. Moghaddami A., Gerek Z., Karimiasl A., Nozohourie H. Evaluation of Acute Dehydration Impacts on Elite Wrestlers' Single-Leg Takedown Technique by 3D Motion Analysis. Medicina dello Sport, 2018, vol. 71 (1), pp. 1-10.

7. Morozov A.V. Delovaya psikhologiya [Business Psychology]. St. Petersburg, Union Publ., 1999. 118 p.

8. Provenzano S., Santangelo O.E., Firenze A. Factors Associated with the Anxious Symptomatology in a Sample of University Students. Minerva Psichiatrica, 2018, vol. 59 (4), pp. 165-170. DOI: 10.23736/S0391-1772.18.01975-1

9. Rajagopalan P., Dixit S., Alahmari K., Devenesan C.S. Resistance Training Influences Adipokines and Various Biochemical Factors Altering the Risk of Metabolic Syndrome in Young Male Obese Students. Medicina dello Sport, 2018, vol. 71 (4), pp. 561-578. DOI: 10.23736/S0025-7826.18.03431-2

10. Rodionova T.I., Tepayeva A.I. [Obesity is a Global Problem of Modern Society]. Fundamental'nyye issledovaniya [Fundamental Research], 2012, no. 12-1, pp. 132-136. (in Russ.)

11. Savchikova Yu.L. [Personal Features of Women with Overweight]. Mezhdunarodnyy meditsinskiy zhurnal [International Medical Journal], 2004, vol. 10, no. 3, pp. 83-88. (in Russ.)

12. Singh H., Bhaumik U. Weight Loss Associated with Clozapine: Mechanism and Review of Literature. Minerva Psichiatrica, 2018, vol. 59 (3), pp. 160-162. DOI: 10.23736/ S0391-1772.18.01970-2

13. Spielberger C.D. Conceptual and Methodological Problems of the Study of Anxiety. Anxiety and Anxiety, 2001, pp. 88-103.

14. Tungaraza T.E. Significant Weight Loss Following Clozapine Use, how is it Possible? A Case Report and Review of Published Cases and Literature Relevant to the Subject. Ther Adv Psychopharmacol, 2016, no. 6, pp. 335-342. DOI: 10.1177/2045125316649534

15. Vakhmistrov A.V., Voznesenskaya T.G., Posokhov S.I. [Clinical and Psychological Analysis of Eating Disorders in Obesity]. Zhurnal nevrologii $i$ psikhiatrii imeni S.S. Korsakova [Journal of Neurology and Psychiatry Named after S.S. Korsakov], 2001, no. 12, pp. 19-24. (in Russ.)

16. Werneke U., Taylor D., Sanders T.A. Behavioral Interventions for Antipsychotic Induced Appetite Changes. Curr Psychiatry Rep, 2013, vol. 15 , 347 p. DOI: 10.1007/s11920-0120347-y

17. Zaccagni L., Rinaldo N., Bramanti B., Gualdi-Russo E. Relation Between Lifestyle Behaviors and Body Composition Patterns Among Healthy Young Italians: a Cross-Sectional Study. The Journal of Sports Medicine and Physical Fitness, 2018, vol. 58 (11), pp. 1652-1656. DOI: 10.23736/S0022-4707.17.07871-9

Received 15 March 2019 


\title{
ПСИХОФИЗИОЛОГИЧЕСКИЙ СТАТУС ЛИЦ С ИЗБЫТОЧНЫМ ВЕСОМ
}

\author{
Т.В. Попова', Б. Панс ${ }^{2}$, Г.И. Максутова', Ю.Б. Кораблева ${ }^{1}$, О.Г. Коурова ${ }^{1}$ \\ ${ }^{1}$ Южно-Уральский государственный университет, г. Челябинск, Россия, \\ ${ }^{2}$ Академия Ле Панс, г. Париж, Франция
}

Цель. Выявить психофизиологические особенности женщин с проблемами избыточного веса для дальнейшей разработки комплекса, включающего средства для снижения веса и психокоррекции. Материалы и методы. Исследованы две группы женщин, пожелавших заниматься по программе коррекции веса: 1 -я - средний возраст 54,2 \pm 3,0 и 2-я $25,0 \pm 1,7$ года. В 1-й группе средний индекс массы тела $(32,3 \pm 1,6)$ свидетельствовал об ожирении; во 2-й группе $(23,7 \pm 0,9)$ он был на верхней границе нормы, но существовал риск его повышения. Так, процент жировой ткани превышал рекомендуемые цифры, и рекомендуемая потеря веса составила для старшей группы 18,2 $\pm 2,6$ кг, а для молодых испытуемых 5,6 $\pm 1,4$ кг. В качестве контрольных обследованы две группы женщин того же возраста, с нормальным весом. Результаты. Исследования выявили как возрастные, так и особенности психофизиологических показателей у женщин с разным весом. Амплитуда альфа-ритма ЭЭГ у испытуемых 1-й группы была ниже, а частота - выше; выявлен также более высокий уровень активности дельта диапазона в лобной области в покое, чем у женщин контрольной группы. Исследование психоэмоционального состояния показало, что все испытуемые относились к категории лиц, с трудом справляющихся со стрессами. Однако молодые испытуемые легче справляются со стрессовой ситуацией по сравнению со старшими. Результаты оценки тревожности показали ее повышенный уровень, у всех испытуемых групп наблюдения личностная тревожность была практически аналогичной, в пределах 48 баллов. Уровень же ситуационной тревожности у молодых женщин был выше, чем у старших (51,2 $\pm 1,3$ и 49,6 $\pm 2,1$ балла соответственно). Заключение. Большинство психофизиологических показателей свидетельствовали о функциональном напряжении, особенно у женщин старшего возраста с избыточным весом. Сделано заключение, что для сохранения оптимального психофизиологического статуса лиц, участвующих в программах по коррекции веса, необходима также коррекция психофизического состояния с учетом возрастных особенностей.

Ключевые слова: избыточный вес, возраст, структура тканей тела, электроэниефалография, психоэмоциональное состояние, функииональное напряжение.

\section{Лumepamypa}

1. Trauma and multi-impulsivity in the eating disorders / E. Corstorphine, G. Waller, R. Lawson, C. Ganis // Eating Behaviors. - 2007. - № 8. - P. 23-30. DOI: 10.1016/j.eatbeh2004.08.009

2. Доскин, В.А. Профилактика экзаменационного стресса / В.А. Доскин // Школа и психическое здоровье учашихся / под ред. С.М. Громбаха. - М.: Медииина, 1988. - C. 147-160.

3. Psychological aspects of obesity / A.N. Fabricatore, T.A. Wadden // Clinics in Dermatology. 2004. - Vol. 22 (4). - P. 332-337. DOI: 10.1016/j.clindermatol.2004.01.006

4. Effect of 7-minute workout on weight and body composition / L. Mattar, N. Farran, D. Bakhour // The Journal of Sports Medicine and Physical Fitness. - 2017. - October, 57 (10). - P. 1299-1304. DOI: 10.23736/S0022-4707.16.06788-8

5. Body composition analysis to study long-term training effects in elite male water polo athletes / G. Melchiorri, V. Viero, R. Sorge et al. // The Journal of Sports Medicine and Physical Fitness. - 2018. September, Vol. 58 (9). - P. 1269-1274. DOI: 10.23736/S00224707.17.07208-5

6. Evaluation of acute dehydration impacts on elite wrestlers' single-leg takedown technique by 3D motion analysis/ A. Moghaddami, Z. Gerek, A. Karimiasl, H. Nozohourie // Medicina dello Sport. 2018. - Vol. 71 (1). - P. 1-10.

7. Морозов, А.В. Деловая психология / А.В. Морозов. - СПб.: Союз, 1999. - 118 c. 


\section{Физиология}

8. Factors associated with the anxious symptomatology in a sample of university students / S. Provenzano, O.E. Santangelo, A. Firenze // Minerva Psichiatrica. - 2018 December. - Vol. 59 (4). P. 165-170. DOI: 10.23736/S0391-1772.18.01975-1

9. Resistance training influences Adipokines and various biochemical factors altering the risk of metabolic syndrome in young male obese students / P. Rajagopalan, S. Dixit, K. Alahmari, C.S. Devenesan // Medicina dello Sport. - 2018. - Vol. 71 (4). - P. 561-78. DOI: 10.23736/S0025-7826.18.03431-2

10. Родионова, Т.И. Ожирение - глобальная проблема современного общества / Т.И. Родионова, А.И. Тепаева // Фундаментальные исследования. - 2012. - № 12-1. - С. 132-136.

11. Савчикова, Ю.Л. Личностные особенности женщин с избыточной массой тела / Ю.Л. Савчикова // Междунар. мед. журнал. - 2004. - Т. 10. - № 3. - С. 83-88.

12. Weight loss associated with clozapine: mechanism and review of literature / H. Singh, U. Bhaumik // Minerva Psichiatrica. - 2018. - Vol. 59 (3). - P. 160-162. DOI: 10.23736/ S0391-1772.18.01970-2

13. Spielberger, C.D. Conceptual and methodological problems of the study of anxiety / C.D. Spielberger // Anxiety and anxiety. St. Petersburg. - 2001. - P. 88-103.

14. Significant weight loss following clozapine use, how is it possible? A case report and review of published cases and literature relevant to the subject / T.E. Tungaraza // Ther Adv Psychopharmacol. 2016. - № 6. - P. 335-342. DOI: 10.1177/2045125316649534

15. Вахмистров, А.В. Клинико-психологический анализ нарушений пищевого поведения при ожирении / А.В. Вахмистров, Т.Г. Вознесенская, С.И. Посохов // Журнал неврологии и психиатрии им. С.С. Корсакова. - 2001. - № 12. - C. 19-24.

16. Behavioral interventions for antipsychotic induced appetite changes / U. Werneke, D. Taylor, T.A. Sanders // Curr Psychiatry Rep. - 2013. - Vol. 15. - P. 347. DOI: 10.1007/s11920-012-0347-y

17. Relation between lifestyle behaviors and body composition patterns among healthy young Italians: a cross-sectional study / L. Zaccagni, N. Rinaldo, B. Bramanti, E. Gualdi-Russo // The Journal of Sports Medicine and Physical Fitness. - 2018. - Vol. 58 (11). - P. 1652-1656. DOI: 10.23736/S0022-4707.17.07871-9

Попова Татьяна Владимировна, доктор биологических наук, профессор, ведущий эксперт, Южно-Уральский государственный университет. 454080, г. Челябинск, проспект Ленина, 76. E-mail: tati.popova2010@yandex.ru, ORCID: 0000-0002-5060-8132.

Панс Бенедикт, доктор физиологии, директор академии Ле Панс. Ул. Фобур Сен-Дени, 162, Париж, 75010, Франция. E-mail: lepansebénédicte@yahoo.fr.

Максутова Гульнара Илгисовна, кандидат биологических наук, доцент кафедры спортивного совершенствования, Южно-Уральский государственный университет. 454080, г. Челябинск, проспект Ленина, 76. E-mail: sandugac2011@yandex.ru, ORCID: 0000-0002-5518-9459.

Кораблева Юлия Борисовна, лаборант, Южно-Уральский государственный университет. 454080, г. Челябинск, проспект Ленина, 76. E-mail: julya-74@yandex.ru, ORCID: 0000-0003-2337-3531.

Коурова Ольга Германовна, кандидат биологических наук, доцент кафедры экологии и химической технологии, Южно-Уральский государственный университет. 454080, г. Челябинск, проспект Ленина, 76. E-mail: olga.k5691@mail.ru, ORCID: 0000-0002-8544-7631.

Поступила в редакцию 15 марта 2019 z.

\section{ОБРАЗЕЦ ЦИТИРОВАНИЯ}

Psychophysiological Status in Overweight Individuals / T.V. Popova, B. Pance, G.I. Maksutova et al. // Человек. Спорт. Медицина. - 2019. - Т. 19, № 2. C. $20-26$. DOI: $10.14529 / \mathrm{hsm} 190203$

\section{FOR CITATION}

Popova T.V., Pance B., Maksutova G.I., Korableva Yu.B., Kourova O.G. Psychophysiological Status in Overweight Individuals. Human. Sport. Medicine, 2019, vol. 19, no. 2, pp. 20-26. DOI: 10.14529/hsm190203 